\title{
Microarray Analysis of Normal and Abnormal Chick Ventricular Myocardial Development
}

\author{
E. KREJČI Íl, ${ }^{1, *}$, Z. PESEVSKI ${ }^{1,2^{*}}$, A. C. DEALMEIDA ${ }^{3}$, M. MRUG ${ }^{4}$, V. M. FRESCO ${ }^{3}$, \\ W. S. ARGRAVES ${ }^{3}$, J. L. BARTH ${ }^{3}$, X. CUI $^{4}$, D. SEDMERA $^{1,2,3}$ \\ ${ }^{*}$ These authors contributed equally.
}

${ }^{1}$ Institute of Anatomy, First Faculty of Medicine, Charles University, Prague, Czech Republic,

${ }^{2}$ Institute of Physiology, Academy of Sciences of the Czech Republic, Prague, Czech Republic,

${ }^{3}$ Department of Regenerative Medicine and Cell Biology, Medical University of South Carolina, Charleston, South Carolina, USA, ${ }^{4}$ Division of Nephrology, University of Alabama at Birmingham, Birmingham, Alabama, USA

Received April 23, 2012

Accepted May 15, 2012

\section{Summary}

The left and right ventricle originate from distinct parts of the cardiac tube, and several genes are known to be differentially expressed in these compartments. The aims of this study were to determine developmental differences in gene expression between the left and right ventricle, and to assess the effect of altered hemodynamic loading. RNA was extracted from isolated left and right normal chick embryonic ventricles at embryonic day 6, 8, and 10 , and from day 8 left atrial ligated hearts with hypoplastic left and dilated right ventricles. CRNA was hybridized to Affymetrix Chicken Genome array according to manufacturer protocols. Microarray analysis identified 302 transcripts that were differentially expressed between the left and right ventricle. Comparative analysis detected 91 genes that were different in left ventricles of ligated hearts compared to age-matched ventricles, while 66 were different in the right ones. A large number of the changes could be interpreted as a delay of normal maturation. The approach described in this study could be used as one of the measures to gauge success of surgical procedures for congenital heart disease and help in determining the optimal time frame for intervention to prevent onset of irreversible changes.

\section{Key words}

Gene chip array • Chick embryo • Left atrial ligation • Hypoplastic left heart syndrome

\section{Corresponding author}

D. Sedmera, Department of Cardiovascular Morphogenesis,
Institute of Physiology, Vídeňská 1083, 14220 Prague, Czech Republic. E-mail: dsedmera@biomed.cas.cz

\section{Introduction}

The evolution of the cardiovascular system has permitted increases in organism growth, size and complexity beyond the metabollic constraints imposed by a diffusion-based system. With the development of an initially open circulatory system, metabolic rate and size in three dimensions could be dramatically increased, enabling the eventual emergence of chordates. The heart is therefore the first adult organ to start functioning during embryogenesis (Kirby 2007).

Development of the myocardium starts during gastrulation with the precardiac mesoderm, organized into cardiac crescent (Kirby 2007). Anteriorly localized cells would normally give rise to the left ventricle, while posteriorly located ones would mostly contribute to the atrial tissues; however, their fates are not firmly set and respond to local environment cues. There is also the second, by some called secondary or anterior, heart field, which gives rise to the right ventricle and the outflow tract (Kelly and Buckingham 2002). As the cells migrate towards the midline, they start to organize themselves into two tubular structures with future endocardium on the inside and myocardium on the outside. In the midline, the fusion process starts first with the endocardial tubes, and later on with myocardium. The primitive cardiac tube 
is initially straight, and is composed of myocardium, acellular cardiac jelly, and endocardium. It consists of the portion that will become the future left ventricle; the presumptive atria are located at the inflow (posterior) end. The first contractions commence in the ventricular segment already during the second day of incubation in the chick (Kamino et al. 1981), and soon the circulation of blood starts.

The crucial process for further morphogenesis and septation of the heart is termed cardiac looping. In a strict sense, the initially straight tube is thus transformed into a cardiac loop, and at that period begins expansion of atrial and ventricular chambers, which acquire their molecular identity. The left and right ventricle become morphologically distinguishable during this "ballooning" period, and the muscular portion of the interventricular septum (compact in mammals, trabeculated in the chick) starts to form between them (Sedmera et al. 2000). The original ("primitive", slowly conducting and contracting) myocardium flanks the atrial and ventricular segments, forming sinus venosus at the inflow (venous) end, atrioventricular canal between the atria and ventricle, and myocardial outflow tract at the outflow (arterial) end. The process of cardiac looping was well described from the morphological point of view by Manner (2000), and the molecular fingerprints of cardiac chambers are continuously updated by the Moorman lab (Sedmera 2005, Rana et al. 2007, Aanhaanen et al. 2009).

Formation of trabeculae in the ventricular chambers is the morphological hallmark of their differentiation and distinguishes these segments from the rest of the heart loop, where the myocardium is organized into a circular, multilayered tube. Ventricular trabeculae express different patterns of genes, such as connexin40 (Becker et al. 1998, Miquerol et al. 2004) that contributes to its higher conduction velocity. It is believed that the primary reason for trabeculation is the necessity to provide sufficient nutrition for increased myocardial mass in the (initial) absence of coronary circulation (Minot 1901, Tota et al. 1983). Indeed, the ventricles of some adult lower vertebrates are organized in such a way (Tota et al. 1983), even though there are coronary arteries present in different parts of those hearts (Sedmera et al. 2003). Such trabeculated hearts work well as volume pumps, but are not suited for generating higher pressure necessary for sustained aerobic performance. Not surprisingly, a different morphological form of the ventricle, dependent primarily on the thick, vascularized outer compact layer, is found in large, fast-swimming fish species (Ostadal and
Schiebler 1971, Agnisola and Tota 1994).

The left and right ventricle originate from distinct parts of the cardiac tube, and several genes are known to be differentially expressed in these compartments (Di Lisi et al. 2000, Moorman and Christoffels 2003). The two chambers differ both morphologically and physiologically after birth, and careful consideration of these differences is essential in planning of surgical procedures in complex forms of congenital heart disease such as hypoplastic left heart syndrome. It is, however, unknown to what extent these differences are pre-programmed from the onset, and how much is due to adaptations to different hemodynamic loading. Due to advances in ultrasound imaging, it is possible to study the function of the trabeculated heart not only in model species (chick, mouse), but also in humans. This leads to increased interest in its normal and abnormal function as a prelude to development of embryonic heart failure (Sedmera 2011).

The goals of this study were to determine developmental differences in gene expression between left and right ventricle, and to assess the differential effect of altered hemodynamic loading on left and right ventricle. In contrast to previous studies focusing on single genes or group of factors, we chose the gene chip array approach for a wide coverage of the transcriptome of the developing heart.

\section{Material and Methods}

Eggs were incubated in a force draft incubator at $37.5^{\circ} \mathrm{C}$ and high humidity until embryonic day (E) 6, 8, or 10 (Hamurger-Hamilton stages 29, 34, and 36). Embryos were removed from the eggs and dissected in RNAlater (Ambion); the left and right ventricles were separated by microdissection (Sedmera et al. 1997, Fig. 1) and aliquoted into sterile $2 \mathrm{ml}$ Eppendorf tubes with RNAlater. Only embryos that appeared externally normal and were of the appropriate stage were used; dysmorphic or growth-retarded embryos were discarded.

\section{Left atrial ligation ( $L A L)$}

Partial ligation of the left atrial appendage was performed in ovo at E4 (Stage 24), as described (Sedmera et al. 1999). Reduction of left atrial volume lead to decreased blood flow across the interatrial septum, resulting in decreased preload of the left and increased preload of the right ventricle. Tissues from Stage 34 (E8) embryos with established phenotype (Fig. 1) were 
carefully dissected, collected and stored in RNAlater, and then pooled for RNA isolation.

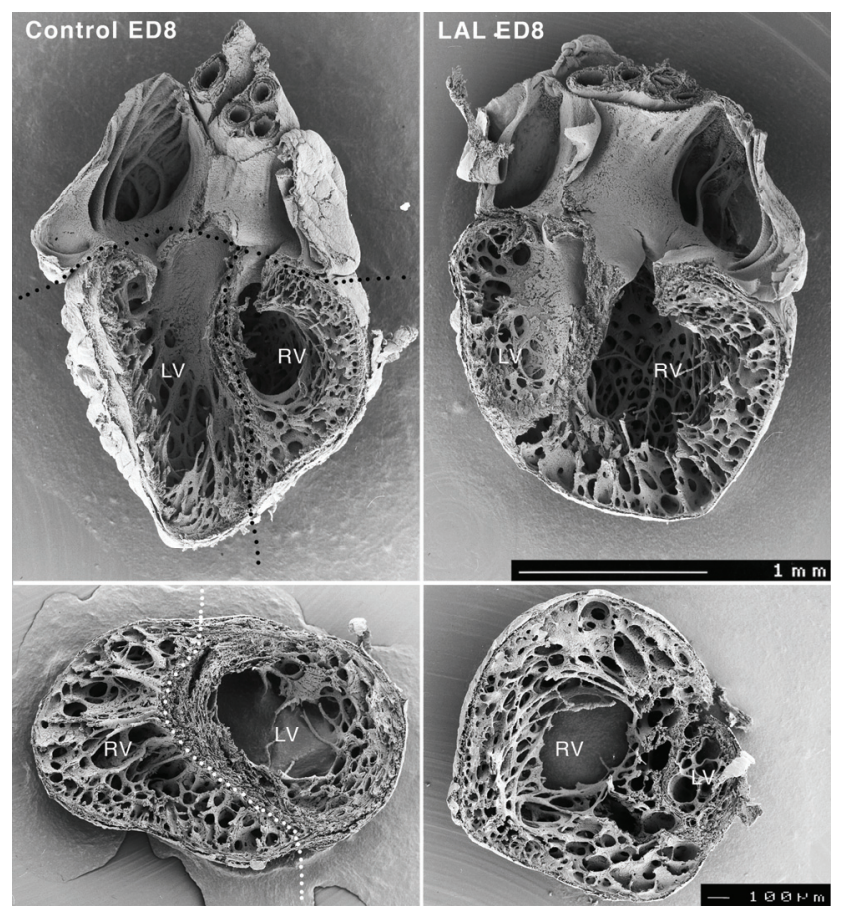

Fig. 1. Phenotype of experimental left heart hypoplasia in scanning electron microscopy. A. control slice at mid-ventricular level illustrating dissection into left (LV) and right (RV) ventricle used for RNA extraction. B. Slice from heart with severe left ventricular hypoplasia showing also dilation of the right ventricle. Scale bar $100 \mu \mathrm{m}$.

Each sample for hybridization contained a minimum of 6 to 12 separate biological specimens. RNA was purified using RNeasy columns (Qiagen), converted into biotin-labeled cRNA targets (Invitrogen SuperScript cDNA synthesis kit and Enzo Bioarray Hi Yield kit), and then hybridized to Affymetrix Chicken Genome arrays (4 $\mu \mathrm{g}$ per hybridization) according to manufacturer protocols. All samples were hybridized in technical duplicates.

Gene hybridization intensities were normalized by gcRMA algorithm (Wu et al. 2005) and detection calls generated by MAS5 algorithm, both implemented with ArrayQuest (Argraves et al. 2005). Data were analyzed by pairwise comparison using the following differential expression criteria: fold change $>4 ; \mathrm{p}<0.05$ (Student's unpaired t-test), and $100 \%$ 'presence' call for either set of technical replicates. Hierarchical clustering of genes was performed with dChip software using a centroid linkage model with distance metric. The microarray protocol adhered to MIAME standards. The data discussed in this publication have been deposited in
NCBI's Gene Expression Omnibus and are accessible through GEO Series accession number GSE37070 (http://www.ncbi.nlm.nih.gov/geo/query/acc.cgi?acc= GSE37070). Functional enrichment of biological processes was conducted with the DAVID functional annotation tool (Huang da et al. 2009a,b). Biological processes with p-values $<0.005$ were considered significant.

\section{Results}

Developmental differences between left and right ventricle

Microarray analysis identified 302 transcripts that were differentially expressed between the left and right ventricle at developmental stages E6, E8 and E10 (Fig. 2). Overall, the number of genes differentially expressed between left and right ventricle at a given stage increased progressively with embryonic age, suggesting an increasing functional divergence of the ventricles as developmental advanced. There were 103 genes different at E6, 99 at E8, and 150 at E10. Of the entire 302, 255 were different at only one stage, 44 were different at 2 stages, and only 3 were different at all three stages by our statistical criteria. Thus, the genes different at each stage were largely independent, non-ovelapping groups. These observations are consistent with use of distinct transcriptional programs during advancing ventricular differentiation.

Examination of developmental profiles of the 302 genes different between left and right ventricles revealed several interesting patterns. For example, there was a fair number of genes that were progressively down-regulated with advancing development, especially, and sooner in the left ventricle (Fig. 2, Box \#1). On the other hand, there was a small cluster of genes that were selectively upregulated in the right ventricle, and more strongly so with advancing development (Fig. 2, Box \#2). It is also appreciable that the changes in the left ventricle often preceded those in the right ventricle by approximately 2 days.

Expression data for all 302 genes satisfying the differential expression criteria are included in Supplemental Table 1 (in on-line version only). Analysis of biological processes associated with the 302 genes confirmed that heart development and morphogenesis genes were significantly enriched in this group (Table 1). Other notable significant processes were cardiac cell differentiation, positive regulation of phosphorylation, extracellular region, and transforming growth factor-beta-related. 
Table 1. Functional categories enriched for 302 genes differentially expressed between left and right ventricles at E6, E8 and E10 developmental stages.

\begin{tabular}{|c|c|c|c|}
\hline $\begin{array}{l}\text { Biological } \\
\text { Process }\end{array}$ & Process ID $^{1}$ & Count $^{2}$ & P-Value ${ }^{3}$ \\
\hline $\begin{array}{l}\text { Appendage } \\
\text { development }\end{array}$ & $\begin{array}{c}\mathrm{GO}: 004873 \\
6\end{array}$ & 10 & $<0.0001$ \\
\hline $\begin{array}{l}\text { Heart } \\
\text { development }\end{array}$ & $\begin{array}{c}\mathrm{GO}: 000750 \\
7\end{array}$ & 11 & $<0.0001$ \\
\hline $\begin{array}{l}\text { Embryonic } \\
\text { morphogenesis }\end{array}$ & $\begin{array}{c}\text { GO:004859 } \\
8\end{array}$ & 12 & $<0.0001$ \\
\hline $\begin{array}{l}\text { Heart } \\
\text { morphogenesis }\end{array}$ & $\begin{array}{c}\mathrm{GO}: 000300 \\
7\end{array}$ & 6 & 0.0001 \\
\hline $\begin{array}{l}\text { Growth factor } \\
\text { activity }\end{array}$ & $\begin{array}{c}\mathrm{GO}: 000808 \\
3\end{array}$ & 8 & 0.0003 \\
\hline Growth & $\begin{array}{c}\mathrm{GO}: 004000 \\
7\end{array}$ & 7 & 0.0004 \\
\hline $\begin{array}{l}\text { Cell-cell } \\
\text { signaling }\end{array}$ & $\begin{array}{c}\mathrm{GO}: 000726 \\
7\end{array}$ & 8 & 0.0006 \\
\hline $\begin{array}{l}\text { Sensory organ } \\
\text { development }\end{array}$ & $\begin{array}{c}\mathrm{GO}: 000742 \\
3\end{array}$ & 8 & 0.0008 \\
\hline $\begin{array}{l}\text { Palate } \\
\text { development }\end{array}$ & $\begin{array}{c}\mathrm{GO}: 006002 \\
1\end{array}$ & 4 & 0.0011 \\
\hline $\begin{array}{l}\text { Positive } \\
\text { regulation of } \\
\text { cellular protein } \\
\text { metabolic process }\end{array}$ & $\begin{array}{c}\text { GO: } 003227 \\
0\end{array}$ & 6 & 0.0012 \\
\hline $\begin{array}{l}\text { Cardiac cell } \\
\text { differentiation }\end{array}$ & $\begin{array}{c}\text { GO:003505 } \\
1\end{array}$ & 4 & 0.0016 \\
\hline $\begin{array}{l}\text { Skeletal system } \\
\text { development }\end{array}$ & $\begin{array}{c}\mathrm{GO}: 000150 \\
1\end{array}$ & 8 & 0.0021 \\
\hline $\begin{array}{l}\text { Positive } \\
\text { regulation } \\
\text { of phosphorylation }\end{array}$ & $\begin{array}{c}\text { GO:004232 } \\
7\end{array}$ & 5 & 0.0021 \\
\hline $\begin{array}{l}\text { Forebrain } \\
\text { development }\end{array}$ & $\begin{array}{c}\mathrm{GO}: 003090 \\
0\end{array}$ & 6 & 0.0028 \\
\hline $\begin{array}{l}\text { Extracellular } \\
\text { region }\end{array}$ & $\begin{array}{c}\text { GO: } 000557 \\
6\end{array}$ & 18 & 0.0034 \\
\hline Tube development & $\begin{array}{c}\mathrm{GO}: 003529 \\
5\end{array}$ & 7 & 0.0047 \\
\hline $\begin{array}{l}\text { Transforming } \\
\text { growth factor- } \\
\text { beta-related }\end{array}$ & IPR:015615 & 4 & 0.0048 \\
\hline
\end{tabular}

${ }^{1}$ Biological process ID from the Gene Ontology or Interpro database. ${ }^{2}$ Number of unique genes associated with the biological process functional tag. ${ }^{3} \mathrm{P}$-value for biological process enrichment.

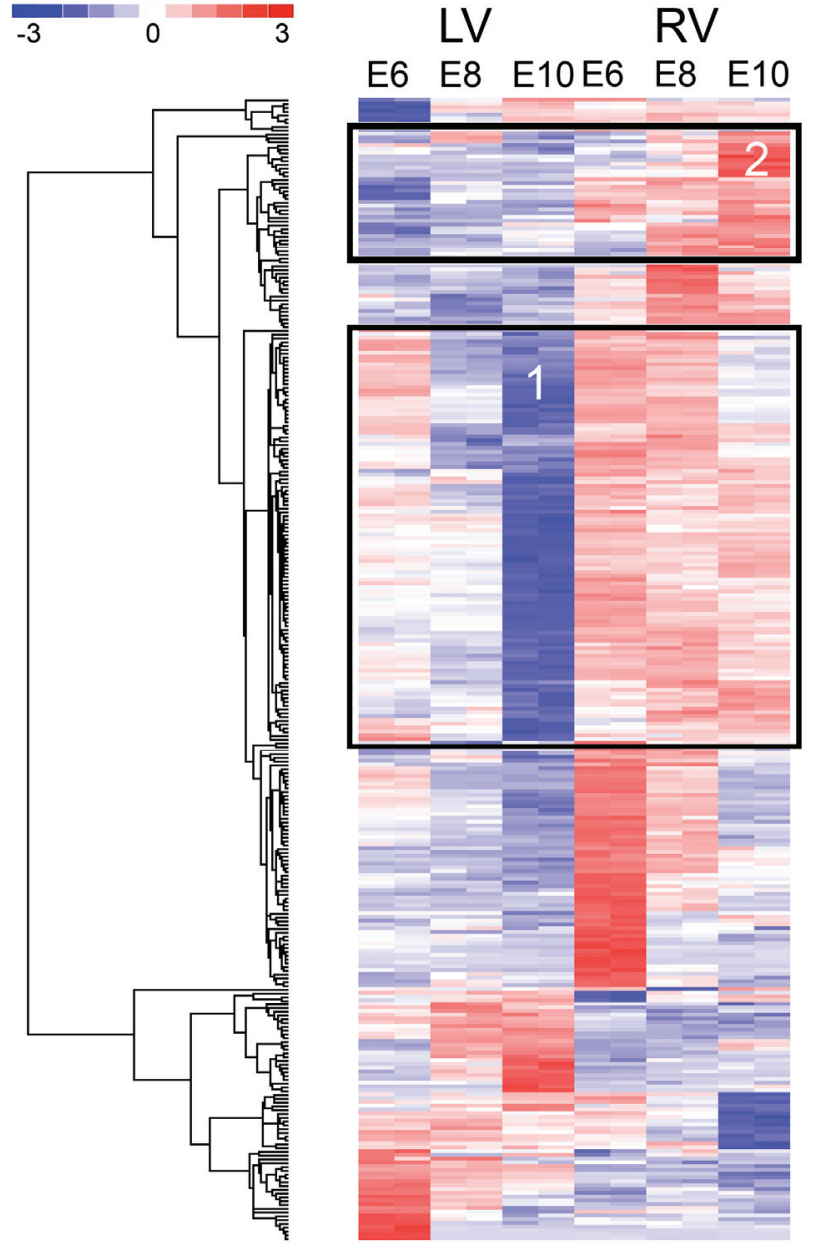

Fig. 2. Heat map of longitudinal changes in gene expression between left and right ventricle. Boxes 1 and 2 show genes upregulated in the right ventricle and downregulated in the left ventricle (blue) with advancing development, respectively. Detailed description of individual transcripts is provided in Supplemental Table 1 (in on-line version only). Hierarchical clustering of expression patterns is shown in dendrogram (left). Colorimetric scaling of the standardized gene expression values (z-scores) ranging from low (blue) to high (red) is shown in the legend (upper left). E6-E8, embryonic days, LV, left ventricle, RV, right ventricle.

Changes under experimentally altered loading conditions

We next analyzed the microarray data to identify genes significantly different in left and right ventricles at E8 as a consequence of LAL. Comparative analysis detected 91 genes that were different in left ventricles of ligated hearts compared to age-matched ventricles (Supplemental Table 2, in on-line version only), while 66 were different in the right ventricles compared to agematched ventricles (Supplemental Table 3, in on-line version only). Review of these genes showed that 21 were shared between the groups affected in left and right 
ventricles. Analysis of biological processes associated with these genes revealed that secretion $(p=0.0005)$, extracellular region $(\mathrm{p}=0.0006)$, and signal peptide $(p=0.002)$ were significantly enriched among genes affected in left ventricle. However, a similar analysis of genes affected in right ventricle did not detect any significantly enriched biological processes $(p<0.005)$, although the category of signal peptide gave the highest enrichment score $(\mathrm{p}=0.03)$.

Developmental expression patterns of the genes affected in E8 left and right ventricles by LAL are shown in Figure 3 (left ventricle, left panel; right ventricle, right panel). Collectively, a large number of the changes in expression could be interpreted as a delay of normal maturation, i.e., the gene expression pattern in the ligated hearts is reminiscent of the earlier developmental stage. In the left ventricle, there were 53 transcripts (58\%) showing this pattern, and 47 in the right ventricle (71\%). Some of these genes showed a lack of normal developmental upregulation (blue in the experimental group, similar to the earlier control stage, but red in same age and older controls; Fig. 3, yellow shading), while others showed a lack of downregulation (red in the experimental group, similar to the earlier control stage, but blue in same age and older controls; Fig. 3, green shading). In the overloaded right ventricle, the majority of differentially expressed genes $(70 \%)$ exhibited this signature of defective up- or downregulation, suggestive of an overall delay in the embryonic program.

\section{Discussion}

The developmental approach in experimental and clinical cardiology is of crucial importance. Epidemiological studies have shown that the risk factors of serious cardiovascular diseases, such as atherosclerosis and ischemic heart disease, are present already during the early phases of ontogenetic development. It follows that experimental studies of the pathogenetic mechanisms of these disturbances must shift to the early ontogenetic period. Therefore, the interest of theoretical and clinical cardiologists in the developmental approach keeps increasing. Recent advances of molecular biology and the developing possibilities of prenatal cardiology accelerated this trend substantially.

Congenital cardiovascular anomalies remain the single largest cause of infant mortality from congenital defects in industrialized countries. In case of patients operated for hypoplastic left heart syndrome using

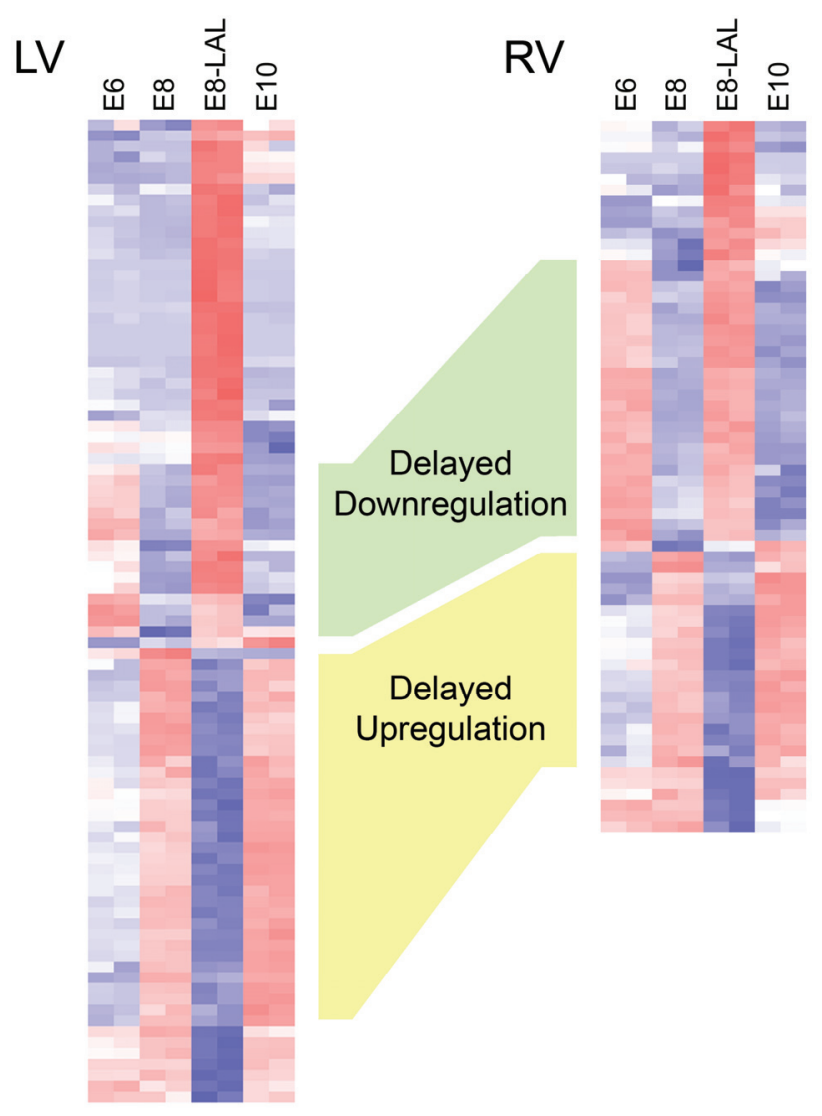

Fig. 3. Heat map of changes in gene expression patterns in chick experimental left heart hypoplasia at embryonic day 8. For developmental perspective and interpretation, expression levels of particular genes at stages 48 hours before and after are added. Comparing the color (blue for decrease, red for increase), it is obvious that the changes indicate shift towards earlier expression pattern in both ventricles in the majority of differentially expressed transcripts. E6-E8, embryonic days, LV, left ventricle, RV, right ventricle, $\mathrm{H}$, experimental (hypoplastic) group. Detailed description of all differentially expressed transcripts is provided in Supplemental Table 2 (in on-line version only).

Norwood palliation ending in complete Fontan (Sedmera et al. 2005), the major problem of those surviving into adolescence is gradual intractable failure of the single right ventricle. Many hypotheses about the possible origin of this failure have been proposed, including ischemic injury during repeated surgical procedures. It has been suggested previously that the right ventricle is not suitable as a long-term systemic pump because of its different geometry (Sedmera et al. 2005). Our study adds to this data by showing that 1) there are significant differences in gene expression patterns between the left and right ventricle already at pre-septation stage, which increase with further development, and 2) hemodynamic perturbation resulting in development of hypoplastic left heart syndrome has profound effects on gene expression 
patterns, which are suggestive of developmental delay. This is not suprising in the underloaded left ventricle, where decreased expression of growth factors and contractile proteins was shown previously by immunohistochemistry (Sedmera et al. 1999, 2002). It is interesting to note that in agreement with our previous morphological and cell proliferation data showing that the right ventricle compensates volume overload by dilation rather than increased myocyte proliferation (Sedmera et al. 1999, 2002), this molecular signature could be interpreted also as a sign embryonic heart failure. Ventricular expression of "fetal gene program" including specific isoforms of contractile proteins (Hirzel et al. 1985) or re-expression of atrial natriuretic peptide (Izumo et al. 1988) is a recognized hallmark in adult hypertrophy or heart failure. We noted previously using ultrasound biomicroscopy that the right atrioventricular valve in LAL hearts shows regurgitation (deAlmeida et al. 2007), similar to pediatric cardiology scenarios. Further studies into other models of embryonic heart failure with documented valve regurgitation, such as conotruncal banding (McQuinn et al. 2007) could confirm this hypothesis.

The results of this experiment are currently subject to verification by RT-PCR, in situ hybridization and immunohistochemistry (in case where antibody is available). One interesting set of candidate genes are extracellular matrix proteins, which could be associated with endocardial fibroelastosis. Edocardial fibroelastosis occurs often in association with human congenital cardiovascular anomalies (Forfar et al. 1964), most notably hypoplastic left heart syndrome, aortic stenosis, aortic atresia or patent ductus arteriosus. The endocardial thickening is believed to be caused by persistent and increased wall tension in the ventricles, possibly secondary to damaged myocardium.

One crucial question is the potential reversibility of changes in myocardial architecture induced by hemodynamic alterations. Our earlier study showed that experimental reversal of altered hemodynamics in the left atrial ligation by means of right atrial clipping
(deAlmeida et al. 2007) results in a rapid increase in myocyte proliferation in the hypoplastic left ventricle and augmentation of myocardial volume. Currently, the infants with hypoplastic left heart syndrome are operated after birth, but some studies (Foker et al. 1999) suggest that corrective surgery (biventricular repair) has a higher likelihood of success if performed early after birth, where the growth of myocardium is still based upon cell proliferation. Several clinical studies (Maxwell et al. 1991, Allan et al. 1995, Tworetzky et al. 2004, Makikallio et al. 2006, McElhinney et al. 2009) have reported results of prenatal intervention aimed at prevention of development of the hypoplastic phenotype with variable success. While balloon dilation of severely stenotic aortic valve carries good chance of success with relatively reasonable risk, perforation of prematurely closed foramen ovale did not bring the desired effects despite good technical success (Marshall et al. 2004). The developmental gene chip array approach described in our study could be used as one of the measures to gauge success from the molecular perspective and could help in determining the optimal time frame for intervention prior to onset of irreversible changes.

\section{Conflict of Interest}

There is no conflict of interest.

\section{Acknowledgements}

This project was supported by SC COBRE (NIH RR 16434), the South Carolina INBRE Bioinformatics Core (P20RR16461), MUSC University Research Resource Facilities (Proteogenomics Facility). Further support was from the Ministry of Education VZ 0021620806, PRVOUK-P35/LF1/5, and institutional AV0Z50110509 and RVO: 67985823 from the Academy of Sciences of the Czech Republic. Current support from the Grant Agency of the Czech Republic P302/11/1308 is also gratefully acknowledged. Z. P. is supported by Charles University in Prague, First Faculty of Medicine training fellowship program and GACR 204/09/H084.

\section{References}

AANHAANEN WT, BRONS JF, DOMINGUEZ JN, RANA MS, NORDEN J, AIRIK R, WAKKER V, DE GIER-DE VRIES C, BROWN NA, KISPERT A, MOORMAN AF, CHRISTOFFELS VM: The Tbx2+ primary myocardium of the atrioventricular canal forms the atrioventricular node and the base of the left ventricle. Circ Res 104: 1267-1274, 2009. 
AGNISOLA C, TOTA B: Structure and function of the fish cardiac ventricle: flexibility and limitations. Cardioscience 5: 145-153, 1994.

ALLAN LD, MAXWELL DJ, CARMINATI M, TYNAN MJ: Survival after fetal aortic balloon valvoplasty. Ultrasound Obstet Gynecol 5: 90-91, 1995.

ARGRAVES GL, JANI S, BARTH JL, ARGRAVES WS: ArrayQuest: a web resource for the analysis of DNA microarray data. BMC Bioinformatics 6: 287, 2005.

BECKER DL, COOK JE, DAVIES CS, EVANS WH, GOURDIE RG: Expression of major gap junction connexin types in the working myocardium of eight chordates. Cell Biol Int 22: 527-543, 1998.

DEALMEIDA A, MCQUINN T, SEDMERA D: Increased ventricular preload is compensated by myocyte proliferation in normal and hypoplastic fetal chick left ventricle. Circ Res 100: 1363-1370, 2007.

DI LISI R, SANDRI C, FRANCO D, AUSONI S, MOORMAN AF, SCHIAFFINO S: An atrioventricular canal domain defined by cardiac troponin I transgene expression in the embryonic myocardium. Anat Embryol (Berl) 202: 95-101, 2000.

FOKER JE, BERRY J, STEINBERGER J: Ventricular growth stimulation to achieve two-ventricular repair in unbalanced common atrioventricular canal. Prog Pediatr Cardiol 10: 173-186, 1999.

FORFAR JO, MILLER RA, BAIN AD, MACLEOD W: Endocardial fibroelastosis. Br Med J 2: 7-12, 1964.

HIRZEL HO, TUCHSCHMID CR, SCHNEIDER J, KRAYENBUEHL HP, SCHAUB MC: Relationship between myosin isoenzyme composition, hemodynamics, and myocardial structure in various forms of human cardiac hypertrophy. Circ Res 57: 729-740, 1985.

HUANG DA W, SHERMAN BT, LEMPICKI RA: Bioinformatics enrichment tools: paths toward the comprehensive functional analysis of large gene lists. Nucleic Acids Res 37: 1-13, 2009a.

HUANG DA W, SHERMAN BT, LEMPICKI RA: Systematic and integrative analysis of large gene lists using DAVID bioinformatics resources. Nat Protoc 4: 44-57, 2009 b.

IZUMO S, NADAL-GINARD B, MAHDAVI V: Protooncogene induction and reprogramming of cardiac gene expression produced by pressure overload. Proc Natl Acad Sci U S A 85: 339-343, 1988.

KAMINO K, HIROTA A, FUJII S: Localization of pacemaking activity in early embryonic heart monitored using voltage-sensitive dye. Nature 290: 595-597, 1981.

KELLY RG, BUCKINGHAM ME: The anterior heart-forming field: voyage to the arterial pole of the heart. Trends Genet 18: 210-216, 2002.

KIRBY ML: Cardiac Development. Oxford University Press, New York, 2007, pp 273.

MAKIKALLIO K, MCELHINNEY DB, LEVINE JC, MARX GR, COLAN SD, MARSHALL AC, LOCK JE, MARCUS EN, TWORETZKY W: Fetal aortic valve stenosis and the evolution of hypoplastic left heart syndrome: patient selection for fetal intervention. Circulation 113: 1401-1405, 2006.

MANNER J: Cardiac looping in the chick embryo: a morphological review with special reference to terminological and biomechanical aspects of the looping process. Anat Rec 259: 248-262, 2000.

MARSHALL AC, VAN DER VELDE ME, TWORETZKY W, GOMEZ CA, WILKINS-HAUG L, BENSON CB, JENNINGS RW, LOCK JE: Creation of an atrial septal defect in utero for fetuses with hypoplastic left heart syndrome and intact or highly restrictive atrial septum. Circulation 110: 253-258, 2004.

MAXWELL D, ALLAN L, TYNAN MJ: Balloon dilatation of the aortic valve in the fetus: a report of two cases. $\mathrm{Br}$ Heart J 65: 256-258, 1991.

MCELHINNEY DB, MARSHALL AC, WILKINS-HAUG LE, BROWN DW, BENSON CB, SILVA V, MARX GR, MIZRAHI-ARNAUD A, LOCK JE, TWORETZKY W: Predictors of technical success and postnatal biventricular outcome after in utero aortic valvuloplasty for aortic stenosis with evolving hypoplastic left heart syndrome. Circulation 120: 1482-1490, 2009.

MCQUINN TC, BRATOEVA M, DEALMEIDA A, REMOND M, THOMPSON RP, SEDMERA D: High-frequency ultrasonographic imaging of avian cardiovascular development. Dev Dyn 236: 3503-3513, 2007.

MINOT CS: On a hitherto unrecognised circulation without capillaries in the organs of Vertebrata. Proc Boston Soc Nat Hist 29: 185-215, 1901. 
MIQUEROL L, MEYSEN S, MANGONI M, BOIS P, VAN RIJEN HV, ABRAN P, JONGSMA H, NARGEOT J, GROS D: Architectural and functional asymmetry of the His-Purkinje system of the murine heart. Cardiovasc Res 63: 77-86, 2004.

MOORMAN AF, CHRISTOFFELS VM: Cardiac chamber formation: development, genes, and evolution. Physiol Rev 83: 1223-1267, 2003.

OSTADAL B, SCHIEBLER TH: The terminal blood bed in the heart of fish (in German). Z Anat Entwicklungsgesch 134: 101-110, 1971.

RANA MS, HORSTEN NC, TESINK-TAEKEMA S, LAMERS WH, MOORMAN AF, VAN DEN HOFF MJ: Trabeculated right ventricular free wall in the chicken heart forms by ventricularization of the myocardium initially forming the outflow tract. Circ Res 100: 1000-1007, 2007.

SEDMERA D: Form follows function: developmental and physiological view on ventricular myocardial architecture. Eur J Cardiothorac Surg 28: 526-528, 2005.

SEDMERA D: Function and form in the developing cardiovascular system. Cardiovasc Res 91: 252-259, 2011.

SEDMERA D, COOK AC, SHIRALI G, MCQUINN TC: Current issues and perspectives in hypoplasia of the left heart. Cardiol Young 15: 56-72, 2005.

SEDMERA D, HU N, WEISS KM, KELLER BB, DENSLOW S, THOMPSON RP: Cellular changes in experimental left heart hypoplasia. Anat Rec 267: 137-145, 2002.

SEDMERA D, PEXIEDER T, HU N, CLARK EB: Developmental changes in the myocardial architecture of the chick. Anat Rec 248: 421-432, 1997.

SEDMERA D, PEXIEDER T, RYCHTEROVA V, HU N, CLARK EB: Remodeling of chick embryonic ventricular myoarchitecture under experimentally changed loading conditions. Anat Rec 254: 238-252, 1999.

SEDMERA D, PEXIEDER T, VUILLEMIN M, THOMPSON RP, ANDERSON RH: Developmental patterning of the myocardium. Anat Rec 258: 319-337, 2000.

SEDMERA D, RECKOVA M, DEALMEIDA A, SEDMEROVA M, BIERMANN M, VOLEJNIK J, SARRE A, RADDATZ E, MCCARTHY RA, GOURDIE RG, THOMPSON RP: Functional and morphological evidence for a ventricular conduction system in the zebrafish and Xenopus heart. Am J Physiol Heart Circ Physiol 284: H1152-H1160, 2003.

TOTA B, CIMINI V, SALVATORE G, ZUMMO G: Comparative study of the arterial and lacunary systems of the ventricular myocardium of elasmobranch and teleost fishes. Am J Anat 167: 15-32, 1983.

TWORETZKY W, WILKINS-HAUG L, JENNINGS RW, VAN DER VELDE ME, MARSHALL AC, MARX GR, COLAN SD, BENSON CB, LOCK JE, PERRY SB: Balloon dilation of severe aortic stenosis in the fetus: potential for prevention of hypoplastic left heart syndrome: candidate selection, technique, and results of successful intervention. Circulation 110: 2125-2131, 2004.

WU Z, IRIZARRY RA: Stochastic models inspired by hybridization theory for short oligonucleotide arrays. $J$ Comput Biol 12: 882-893, 2005. 